\title{
Estimating Quality Adjusted Life Year Loss of Persons Disabled by Stroke Using EQ-5D in Korea
}

\author{
Min-Woo Jo ${ }^{1)}$, Sang-Kyu Kim ${ }^{2}$, Jin Yong Lee ${ }^{3)}$, Kyeong-Soo Lee ${ }^{4)}$ \\ Dept. of Preventive Medicine, College of Medicine, University of Ulsan ${ }^{l)}$ \\ Dept. of Preventive Medicine, College of Medicine, Dongguk University ${ }^{2}$ \\ Dept. of Preventive Medicine, College of Medicine, Konyang University ${ }^{3)}$ \\ Dept. of Preventive Medicine and Public Health, College of Medicine, Yeungnam University ${ }^{4}$
}

\section{$\mathrm{EQ}-5 \mathrm{D}$ 를 이용한 뇌졸중 장애인의 질보정수명 감소분 추정}

\author{
조민우", 김상규 ${ }^{2)}$, 이진용 ${ }^{3)}$, 이경수 ${ }^{4)}$
}

울산대학교 의과대학 예방의학교실"1, 동국대학교 의과대학 예방의학교실 ${ }^{2)}$ 건양대학교 의과대학 예방의학교실 ${ }^{3)}$, 영남대학교 의과대학 예방의학교실 ${ }^{4}$

\section{$=$ Abstract $=$}

목적: 뇌졸중으로 인한 장애인이 증가하고 있으나 이들을 대상으로 질보정수명을 구한 연구가 없었다. 이 연구의 목적은 일개 시에서 뇌졸중 장애인을 대상으로 $\mathrm{EQ}-5 \mathrm{D}$ 로 그들의 건강 관련 삶 의 질 수준을 평가하고, 우리나라 전체 뇌졸중 장애인의 QALYs 감소분을 추정하기 위하여 수행 하였다.

방법: 2008년 3월을 기준으로 경주시 장애인 등록현황에서 50세 이상인 장애인 중 뇌졸중이 원 인으로 파악된 982 명을 대상으로 설문조사자들이 방문하여 대면면접조사를 통해 일반적 특성, 임 상적 특성, $\mathrm{EQ}-5 \mathrm{D}$ 등의 자료를 수집하였다. 제 4 기 국민건강영양조사 에서 일반인구집단과 동반질 환이 없는 군을 건강비교군으로 선정하여 성별, 연령별 표준화를 통해 비교함으로써 효용 가중치 차이를 구하였다. 이 효용 가중치 차이를 우리나라 전체 뇌졸중 장애인에 적용하여 전체 QALYs 감소분을 추정하였다.

결과: 대상자 982 명 중 조사응답자는 566명으로 응답률은 $57.6 \%$ 였다. 여성, 70 대 이상군에서 EQ-5D 지표값이 남성이나 60대 이하군에 비해 더 낮았고, 상대 비교군과의 차이도 크게 나타났다. 건강비교군과 일반인구집단 비교군과의 비교에 따른 전체 QALYs 감소분은 각각 연간 67,011.6 QALYS와 54,167.1 QALYs로 추정되었다.

결론: $\mathrm{EQ}-5 \mathrm{D}$ 로 우리나라 전체 뇌졸중장애인의 QALYs 감소분을 추정하였고, 이 연구를 바탕 으로 뇌졸중 장애인을 대상으로 한 공중보건정책의 집행이나 평가를 수행하여 보다 근거에 기반 한 장애인 정책을 수행할 수 있을 것으로 생각한다.

Key words: HRQOL, Utility, QALY, Stroke, Persons disabled

* 접수일(2011년 6월 2일), 수정일(2011년 6월 23일), 게재확정일(2011년 6월 24일)

* 교신저자: 이경수, 대구광역시 남구 대명5동 317-1 영남의대 예방의학교실

Tel: 053-620-4373, Fax: 053-653-2061, E-mail: drkslee@ynu.ac.kr

* This work was supported by Basic Science Research Program through the National Research Foundation of Korea(NRF) funded by the Ministry of Education, Science and Technology(MEST)"(KRF-2007-331-E00053) 


\section{Introduction}

The number of registered disabled persons was raised over two times from 950 thousands in 2000 to 2240 thousands in 2008 and it is expected to increase continuously due to the population aging and the expansion of the criteria of disability in Korea [1]. In particular, disability of brain lesion was included in the category of disability according to the expansion of the range in 2000. And the number of persons disabled from 30 thousand in 2000 from that time to 230 thousand in 2008[1]. Among many causes of brain lesion, stroke accounts for the largest portion or around $76.9 \%$ of total cases of brain lesion [2].

Health related quality of life(HRQOL) means quality of life related with health condition and perceived health conditions[3]. HRQOL measures can be divided into three-general health profiles, specific measures and preference based measures [4]. Out of them, preference based measure can obtain quality adjusted life years (QALYs) by calculating utility weight. A QALY is an index summarizing both life years and HRQOL. Utility weight is used for weight of QALY calculation, and generally ' 1 ' represents the perfect health and ' 0 ' means death. For example, one year in perfect HRQOL, i.e. state of utility weight equal to 1.0, assigned 1 QALY and other one year in a state of congestive heart disease of which utility weight is 0.5 equals to 0.5 QALYs. Therefore, in this case, 2 years in congestive heart failure equal to 1 year in perfect HRQOL. This QALY is useful for decision-making in the public health and the clinical sectors and for economic evaluation [4]. Preference-based measures widely used are EQ-5D [5], QWB[6], HUI mark3[7] and SF-6D[8].
Out of them, EQ $-5 \mathrm{D}$ was developed by EuroQol group and consists of five dimensions such as mobility, self-care, usual activities, pain/discomfort, and anxiety/depression. Each dimension was assessed on a 3-point ordinal such as no problem, some or moderate problems, extreme problems [5]. EQ-5D has been a common tool to measure HRQOL of the general population and of patients with different diseases such as stroke[9] and diabetes [10]. In addition, valuation sets to calculate utility weight have been suggested in many countries including England [11], the U.S. [12] and Japan [13] using the time trade-off (TTO) method. In South Korea they were also developed by using TTO [14-16].

Although studies assessing HRQOL for stroke patients have been conducted in Korea [17-19], one previous study investigated the correlation between social support and general health profiles [17], another study were conducted with inpatients in one hospital [18]. The other study evaluated some of the general population submitting self-report [19]. But, there was no study measuring burden of disease of persons disabled by stroke in terms of QALYs.

The purposes of this study were to measure health related quality of life (HRQOL) of persons disabled by stroke dwelling in one community of Korea using EQ-5D and to estimate total QALYs loss of persons disabled by stroke in Korea.

\section{Subjects and Methods}

This study targeted persons disabled by stroke aged over 50 years among 1,332 registered as the disabled due to brain lesions in Gyeongju city in March, 2008. Of these, 350 excluded for incompatibility with brain tumor, 
Table 1. Eligible and study subjects by gender and age.

\begin{tabular}{lrrrr}
\hline & \multicolumn{2}{c}{ Eligible population } & \multicolumn{2}{c}{ Study participants } \\
\cline { 2 - 6 } & Male, N (\%) & Female, N (\%) & Male, N (\%) & Female, N (\%) \\
\hline 50 s & $142(25.9)$ & $39(9.0)$ & $64(19.2)$ & $20(8.6)$ \\
$60 \mathrm{~s}$ & $173(31.5)$ & $144(33.3)$ & $118(35.3)$ & $86(37.1)$ \\
$70 \mathrm{~s}$ & $189(34.4)$ & $189(43.6)$ & $130(38.9)$ & $96(41.4)$ \\
80 or over & $45(8.2)$ & $61(14.1)$ & $22(6.6)$ & $30(12.9)$ \\
Total & $549(100.0)$ & $433(100.0)$ & $334(100.0)$ & $232(100.0)$ \\
Mean age $(\mathrm{SD})$ & $67.2(8.9)$ & $70.7(8.4)$ & $67.8(8.3)$ & $70.2(8.3)$ \\
Response rate & & & $60.8 \%$ & $53.6 \%$ \\
\hline
\end{tabular}

Parkinson disease, and brain injury. Out of 982 eligible subjects, 628 agreed to participate in this study. By excluding 62 not completing EQ-5D questionnaire, the data of 566 were finally analyzed. The final response rate was 57.6\%(Table 1).

A questionnaire survey was conducted from June to October 2008. The government officials in charge of chronic disease control and nurses for customized visiting health care in public health centers performed the interviews after receiving educations on the survey. The interviewers informed the eligible subjects of the study by phone, and then visited their homes. This study was approved by Institutional Review Board (IRB) of Dongguk University Gyeongju Hospital.

To calculate QALY loss, comparison data for matching the age groups aged over 50 years were from the 4th Korea Health and Nutrition Examination Survey(KHNES)[20].

In addition, the difference in utility weight was investigated from two aspects. One is the estimated QALY loss from comparison with the healthy control group and the other is from comparison with the general population. First, in comparison with the healthy group, the QALYS losshealthy was estimated using the formula (1).

The number of total disabled persons by stroke was obtained by estimating disabled persons by stroke by age group based on the data of registration of disability due to brain lesion of the Ministry of Health and Welfare in 2008 [21] and National Survey of Disabled Persons in 2008 [2]. The proportion of stroke out of brain lesion by age group recorded $79.2 \%, 89.7 \%$ and $85.3 \%$ for the persons in their 50s, in their 60s and aged over 70 years, respectively [2].

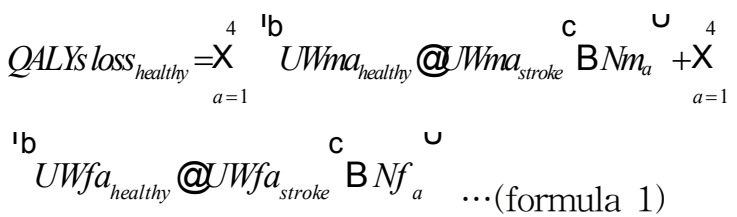

UWmahealthy: Mean utility weight of males of a age group without comorbidity in KHNES

UWmastroke: Mean utility weight of males of a age group in the data of persons disabled by stroke

Nma: An estimate of males disabled by stroke in a age group of South Korea

UWfahealthy: Mean utility weight of females of a age group without comorbidity in KHNES

UWfa $a_{\text {stroke: }}$ Mean utility weight of females of a age group in the data of persons disabled by stroke

$N f_{a}$ : An estimate of females disabled by stroke in a age group of South Korea

a: age group, 1-the 50s, 2-the 60s, 3-the 
70s, 4-the 80s or older

Second, QALYs lossgeneral was calculated from comparison with the general population regardless of existence of comorbidity by using formula (2).

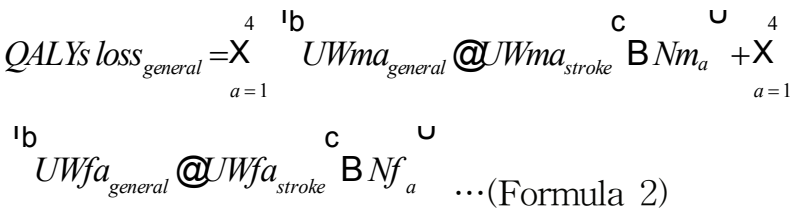

UWmageneral : Mean utility weight of males of a age group in the total data of KHNES

UWfageneral Mean utility weight of females of a age group in the total data of KHNES

Personal characteristics such as gender, age, education and marital status and patterns of alcohol-drinking and smoking after the incidence of stroke were collected by questionnaire survey. And the data of degree of disability and comorbidity were collected by official or medical records. For the disability grade, the grade at the time of 2008 survey was used. Modified Rankin Scale (MRS) and Barthel Index(BI) were assessed by interviewers. To calculate QALYs weight, HRQOL was investigated with EQ-5D. To obtain utility weight or $\mathrm{EQ}^{-5 \mathrm{D}}$ index, the $\mathrm{EQ}^{-5 \mathrm{D}}$ valuation set developed by Lee et al.[14] in South Korea was primarily utilized.

\section{Results}

Among the subjects, males and females were 334(59.0\%) and 232(41.0\%), respectively. For age, the subjects in their 70s accounted for the largest portion in both of males and females. The difference in the distribution of eligible subjects and study subjects by gender was not statistically significant ( $\mathrm{p}^{-}$-value recorded 0.079 and 0.804 in males and females, respectively).
General and clinical characteristics of the participants are shown in Table 2. For educational background, the largest number of the males (111 persons, 33.2\%) graduated elementary schools while the largest number of the females (106 persons, 45.7\%) had no educational background. Although $82.6 \%$ of the males had their spouses, only $47.0 \%$ of the females answered that they had spouses. The rates of alcohol drinkers and smokers were $32.0 \%$ and $26.1 \%$ in males and $11.2 \%$ and $5.4 \%$ in females, respectively. When combined disease was investigated, hypertension ranked first in both of the males and the females $34.7 \%$ and $45.3 \%$, respectively) and diabetes (53 persons, 15.9\%), hyperlipidemia (20 persons, 6.0\%) and backache (20 persons, 6.0\%) followed it in the males while diabetes (35 persons, 15.1\%), osteoarthritis (24 persons, 10.3\%) and cataract (20 persons, 8.6\%) did it in the females. Out of the males and the females, $53.0 \%$ and $43.5 \%$ reported no combined disease, respectively. Duration of disease was within five years in the largest number of the subjects. And the degree of disability was answered to be grade $2(26.9 \%$ and $30.2 \%)$ and grade $3(27.2 \%$ and $27.2 \%)$ of the males and the females, respectively. According to the assessment using MRS, its score was three points in the largest number of the males and the females $(33.5 \%$ and 28.4\%, respectively) and the mean score of Barthel index recorded 14.2 and 13.5, respectively.

The most common problems were usual activities and mobility(Fig. 1). In addition, the EQ-5D health states responded by the largest number of the subjects or $26 \%$ was ' 22222 ' complaining of some problems in all dimensions. As 22221, 33333, 33322 and 33332 followed it in the order, most of the participants were complaint to have problems in mobility, self-care and usual activities. 
Table 2. General and clinical characteristics of study participants.

\begin{tabular}{|c|c|c|c|}
\hline & & Male, N (\%) & $\overline{\text { Female, N (\%) }}$ \\
\hline \multirow[t]{4}{*}{ Education } & No & $59(17.7)$ & $106(45.7)$ \\
\hline & Elementary & $111(33.2)$ & $95(40.9)$ \\
\hline & Middle & $57(17.1)$ & $21(9.1)$ \\
\hline & High or more & $107(32.0)$ & $10(4.3)$ \\
\hline \multirow[t]{2}{*}{ Marital status } & Spouse & $276(82.6)$ & $109(47.0)$ \\
\hline & No spouse & $58(17.4)$ & $123(53.0)$ \\
\hline \multirow[t]{2}{*}{ Drinking } & Yes & $107(32.0)$ & $26(11.2)$ \\
\hline & No & $227(68.0)$ & $206(88.8)$ \\
\hline \multirow[t]{3}{*}{ Smoking* } & Current & $86(26.1)$ & $12(5.4)$ \\
\hline & Former & $176(53.5)$ & $15(6.8)$ \\
\hline & No & $67(20.4)$ & $195(87.8)$ \\
\hline \multirow[t]{6}{*}{ Frequent comorbidity } & Hypertension & $116(34.7)$ & $105(45.3)$ \\
\hline & Diabetes & $53(15.9)$ & $35(15.1)$ \\
\hline & Hyperlipidemia & $20(6.0)$ & $12(5.2)$ \\
\hline & Back pain & $20(6.0)$ & $11(4.7)$ \\
\hline & Osteoarthritis & $18(5.4)$ & $24(10.3)$ \\
\hline & Cataract & $14(4.2)$ & $20(8.6)$ \\
\hline \multirow[t]{3}{*}{ No of comorbidity } & 0 & $177(53.0)$ & $101(43.5)$ \\
\hline & 1 & $84(25.1)$ & $58(25.0)$ \\
\hline & 2 or more & $73(21.9)$ & $73(31.5)$ \\
\hline \multirow[t]{3}{*}{ Prevalent duration ${ }^{\dagger}$} & 5 years or less & $131(39.7)$ & $88(39.1)$ \\
\hline & $6 \sim 10$ years & $114(34.5)$ & $76(33.8)$ \\
\hline & 11 years or more & $85(25.8)$ & $61(27.1)$ \\
\hline \multirow[t]{6}{*}{ Disability grade } & 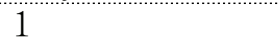 & $51(15.3)$ & $40(17.2)$ \\
\hline & 2 & $90(26.9)$ & $70(30.2)$ \\
\hline & 3 & $91(27.2)$ & $63(27.2)$ \\
\hline & 4 & $56(16.8)$ & $37(15.9)$ \\
\hline & 5 & $30(9.0)$ & $19(8.2)$ \\
\hline & 6 & $16(4.8)$ & $3(1.3)$ \\
\hline \multirow[t]{6}{*}{ Modified Rankin Scale } & 0 & $3(0.9)$ & $1(0.4)$ \\
\hline & 1 & $39(11.7)$ & $22(9.5)$ \\
\hline & 2 & $93(27.8)$ & $65(28.0)$ \\
\hline & 3 & $112(33.5)$ & $66(28.4)$ \\
\hline & 4 & 48 (14.4) & $43(18.5)$ \\
\hline & 5 & $38(11.4)$ & $34(14.7)$ \\
\hline \multicolumn{2}{|l|}{ Barthel index, mean (SD) } & $14.2(6.4)$ & $13.5(6.8)$ \\
\hline
\end{tabular}

*There were missing data of 15 cases.

+ There were missing data of 11 cases.

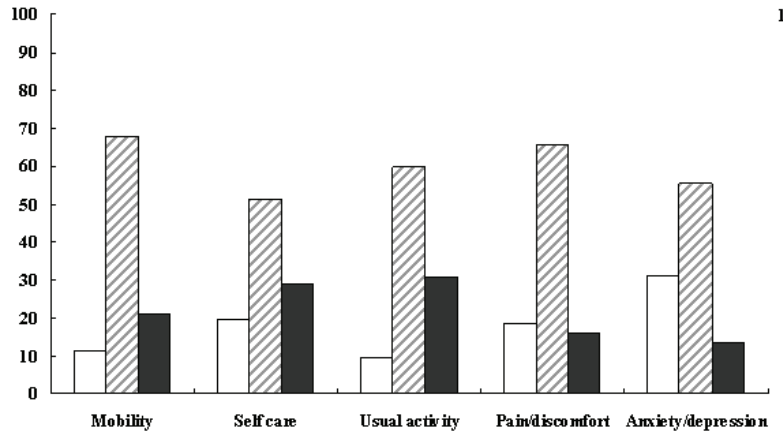

(a) Male

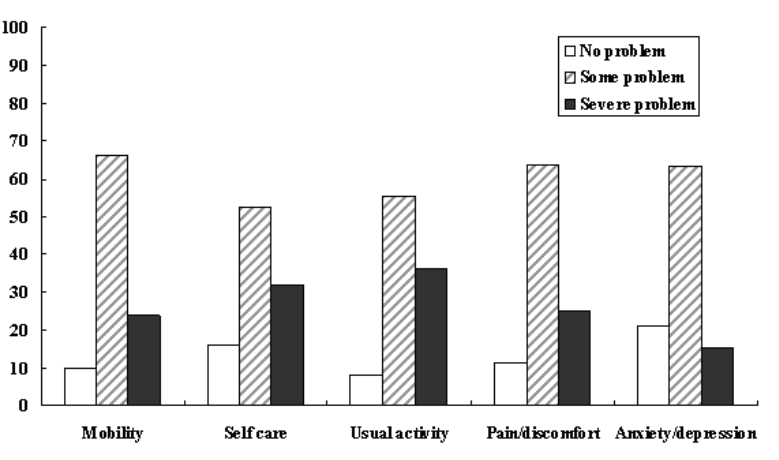

(b) Female

Figure 1. Responses on 5 dimensions of $\mathrm{EQ}^{-} 5 \mathrm{D}$ by gender 


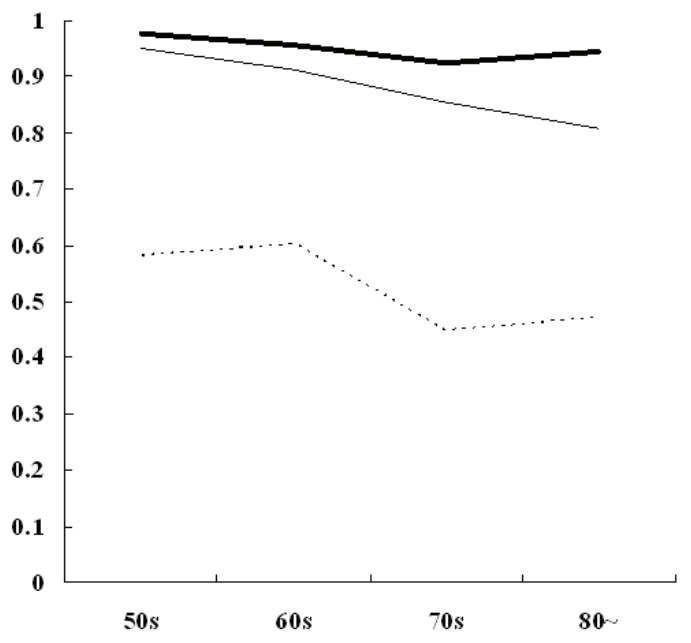

(a) Male

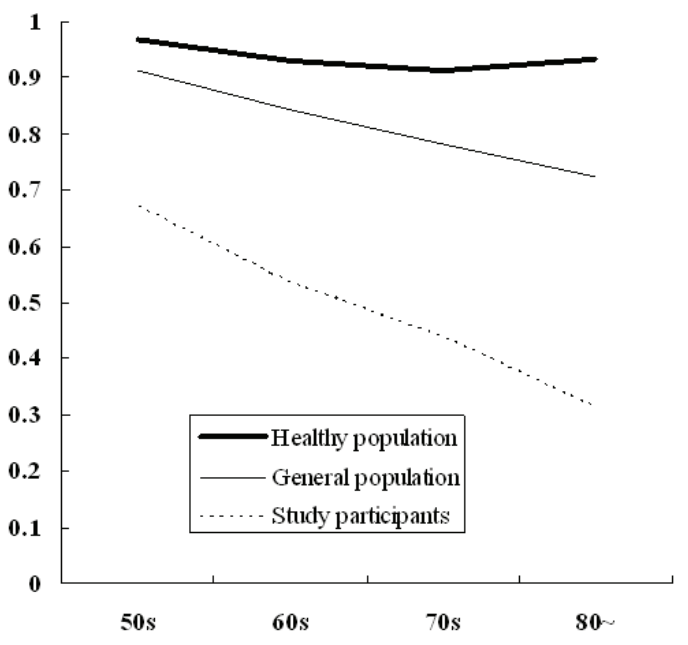

(b) Female

Figure 2. Utility weights of health population, general population, and study participants by age group

Table 3. Frequent EQ-5D health states of the study participants.

\begin{tabular}{ccc}
\hline EQ $-5 D^{-}$health states $^{*}$ & N & $\%$ \\
\hline 22222 & 147 & 26.0 \\
22221 & 47 & 8.3 \\
33333 & 32 & 5.7 \\
33322 & 31 & 5.5 \\
33332 & 23 & 4.1 \\
23322 & 20 & 3.5 \\
11111 & 18 & 3.2 \\
22212 & 18 & 3.2 \\
22211 & 13 & 2.3 \\
21222 & 11 & 1.9 \\
22322 & 11 & 1.9 \\
\hline
\end{tabular}

\footnotetext{
The five digits means five dimensions of $\mathrm{EQ}-5 \mathrm{D}$ health states, i.e. mobility, self care, usual activities, pain/discomfort, and anxiety/depression, and numerals 1, 2, and 3 in each digit represents no problem, some problems, and severe problems, respectively. Therefore, state of '22222' in EQ-5D meant that there were some problems in all 5 dimensions of $\mathrm{EQ}^{-} 5 \mathrm{D}$.
}

\section{Estimating QALY loss}

Difference in utility weight

The utility weights of the disabled persons by stroke, the healthy control group and the general population by age are shown in Fig. 2 . The utility weights of the disabled group were outstandingly lower than those of the healthy control group and the general population. For males, the difference in utility weight between the healthy control group and the general population was the largest in the participants in their 70 s by recording 0.4760 and 0.4045 , respectively. For females, the difference tended to increase with getting older so that it was the largest in the participants in their 80s by recording 0.6171 and 0.4076 , respectively.

\section{Estimating QALY loss}

Estimates of QALY loss are presented in Table 4. In comparison with the healthy group, 
Table 4. Estimating QALY (quality adjusted life year) loss in eligible and study subjects in comparison with health and general population

\begin{tabular}{|c|c|c|c|c|c|c|c|c|}
\hline & \multicolumn{4}{|c|}{ Comparison with healthy population } & \multicolumn{4}{|c|}{ Comparison with general population } \\
\hline & \multicolumn{2}{|c|}{ Eligible population } & \multicolumn{2}{|c|}{ Target population } & \multicolumn{2}{|c|}{ Eligible population } & \multicolumn{2}{|c|}{ Target population } \\
\hline & $\begin{array}{c}\text { Male } \\
\text { (QALYs) }\end{array}$ & $\begin{array}{c}\text { Female } \\
\text { (QALYs) }\end{array}$ & $\begin{array}{c}\text { Male } \\
\text { (QALYs) }\end{array}$ & $\begin{array}{c}\text { Female } \\
\text { (QALYs) }\end{array}$ & $\begin{array}{c}\text { Male } \\
\text { (QALYs) }\end{array}$ & $\begin{array}{c}\text { Female } \\
\text { (QALYs) }\end{array}$ & $\begin{array}{c}\text { Male } \\
\text { (QALYs) }\end{array}$ & $\begin{array}{r}\text { Female } \\
\text { (QALYs) }\end{array}$ \\
\hline $50 \mathrm{~s}$ & 56.4 & 11.5 & 8536.5 & 3035.5 & 52.7 & 9.4 & 7967.1 & 2476.3 \\
\hline $60 \mathrm{~s}$ & 61.3 & 56.5 & 12536.9 & 9037.7 & 53.8 & 44.3 & 11005.2 & 7076.9 \\
\hline $70 \mathrm{~s}$ & 90.0 & 89.6 & 12274.2 & 12647.2 & 76.5 & 64.9 & 10430.5 & 9159.9 \\
\hline 80 or over & 21.4 & 37.6 & 2801.7 & 6141.9 & 15.2 & 24.9 & 1994.6 & 4056.8 \\
\hline \multirow{2}{*}{ Total } & 229.1 & 195.3 & 36149.3 & 30862.3 & 198.1 & 143.4 & 31397.3 & 22769.8 \\
\hline & \multicolumn{2}{|c|}{424.4} & \multicolumn{2}{|c|}{67011.6} & \multicolumn{2}{|c|}{$341.6^{*}$} & \multicolumn{2}{|c|}{$54167.2^{*}$} \\
\hline
\end{tabular}

This caused by rounding error.

QALY loss of disabled persons by stroke in Gyeongju-si and in South Korea were estimated as about 424.4 QALYs and 67,011.6 QALYs, respectively in 2008.

Moreover, in the comparison with the general population, the estimate was 341.6 and 54,167.2 QALYs, respectively. For the difference by gender, QALY loss was larger in males than in females in the comparison with both of the healthy control group and the general population

\section{Discussion}

This study was conducted to estimate QALY loss caused by stroke in Korea. To obtain utility weight, the total disabled persons by stroke in one city(Gyeongju-si) were eligible subjects and one on one interview was performed by visiting them directly.

The total response rate was 57.6\%. Because there was no statistically significant difference by gender and age between the eligible subjects and the study subjects, the data of this study were considered to represent the total disabled persons by stroke well. By comparing these data with those of KHNES, the difference in utility weight by gender and age was examined and QALY loss was obtained by multiplying the difference by an estimated number of disabled persons by stroke.

The disabled persons eligible for the study were all registered stroke in Gyeongju-si and the study subjects included all registered persons disabled by stroke in South Korea. When the eligible subjects and the actual respondents were examined by gender and age, the difference between the two groups was not statistically significant, and their distribution was found to be similar with that of the total disabled persons by stroke in South Korea [2]. Moreover, as the response rate recorded $57.6 \%$, the data collected in this study were thought to be acceptable.

Analysis on health condition of persons disabled by stroke with $\mathrm{EQ}^{-}-5 \mathrm{D}$ revealed that most of the subjects experienced difficulties in usual activities and mobility. By considering that, the data of this study were thought to be collected appropriately. This tendency was similarly observed in general stroke patients. Fischer et al. [9] investigated HRQOL in patients with different types of stroke and found that the rate of complaining of problems related with usual activities was high although it was slightly different according to sites. In addition, it was observed in this study that utility weight was 
lower in females, the score was lower in relatively older group and the difference in comparison with the healthy control group was higher in females and older group, as expected. A study of Jo et al. (2009) [18] also reported a similar tendency, although its results are hard to be compared with those of this study because it was conducted in a hospital. But, the rate of experiencing problems was higher in this study and that was considered to be because the participants of this study were registered disabled persons. For the MRS, most of the participants of this study recorded two or three points and nearly no one did 0 point while a half of the study of Jo et al. (2009) [18] recorded zero or one point. This difference also supports the interpretation mentioned above.

As expected, QALYs loss compared with healthy people larger than that loss compared with general population including some patients. The difference could be caused by self-reported prevalence of diseases. As results based on registered population, QALYs loss was 13.5 QALYs per 10,000 compared with healthy control group and 10.9 QALYs per 10,000 with general population in 2008, respectively.

This study analyzed the data by using the valuation set in a study of Lee et al.[14], but there were other two EQ-5D valuation sets in South Korea [15,16]. So, the estimates were calculated through the same method by using the tables in studies of Jo et al. (2008) [15] and Kang et al. (2006) [16]. Although the overall tendency was similar, but their QALY loss was larger than that using the valuation set of Lee et al. [14] by recording 75486.6 QALYs and 92467.4 QALYs, respectively. This finding shows that the calculated QALYs loss can be different largely by valuation sets. According to a study on value evaluation in Europe, the difference among studies using Visual Analog Scale was relatively small but the difference among those using time-trade off method was larger [22]. Therefore, for studies on burden of disease or economic evaluation, it is needed to draw a conclusion after testing results of analysis using other valuation sets as well as a valuation set utilized in a primary analysis.

This study had some limitations. First, this study estimated the number of disabled persons by stroke by using the total number of registered disabled persons in South Korea and causes of disability by age. Although the number of the registered persons was considered to be similar with an actual number, whether stroke was a cause of disability was not clear. The cause was examined with National Survey of Disabled Persons, but it could produce some errors in estimates because its data did not classify the subjects in their $70 \mathrm{~s}$ and aged over 80 years and into males and females. In addition, although HRQOL could be influenced by various factors including socioeconomic variables such as educational background and income, this study applied only standardization by gender and age, to estimate QALY loss in the total persons disabled by stroke in South Korea due to the lack of data.

Despite these limitations, this study is meaningful as it investigates HRQOL levels of persons disabled by stroke in a community directly by using $\mathrm{EQ}-5 \mathrm{D}$ or HRQOL measurement tool widely used around the world and it estimates QALY loss of the total persons disabled by stroke in South Korea by using the results. With a rapid population aging, the 
number of persons disabled by stroke is expected to increase, so more researches are necessary for persons disabled by stroke to enjoy improved quality of life through interventions by monitoring their HRQOL and by determining factors affecting it.

\section{Summary}

The purposes of this study were to measure health related quality of life (HRQOL) of persons disabled by stroke dwelling in Gyeongju-si using EQ-5D and to estimate total QALYs loss of persons disabled by stroke in Korea.

The eligible subjects were 982 persons with stroke aged 50 and over in Gyeongju-si disabled registry, as of March, 2008. Interviewers measured HRQOL of study subjects using EQ-5D. EQ-5D index, utility weight, was derived from the Korean valuation set. In order to compare the results of this study, we selected two comparison groups representing Korean healthy population and general population of Korean using the 4th Korean National Health \& Nutrition Examination Survey. Finally, after age and gender standardization, we estimated the total QALYs losses of persons disabled by stroke in Korea.

Of 982 eligible subjects, 566 persons participated in the survey (response rate: 57.6\%). In both of female and male, utility weights in the $70 \mathrm{~s}$ or $80 \mathrm{~s}$ were lower than those of the 50 s or 60 s. Utility weights differences among persons with disability, general population, and healthy population in male were larger than those differences in female. Total estimated QALY losses of persons disabled by stroke were 67,011.6 QALYs lower than healthy control group and 54,167.1 QALYs lower than general population, respectively.

\section{References}

1. Ministry of Employment and Labor, Korea Employment Agency for the Disabled. 2009 Statistics for the Disabled. GyeongGi-Do Seongnam City, Korea Employment Agency for the Disabled; 2009, pp.165-170 (Korean)

2. Byeon YC, Kim SH, Yun SY, Kang MH, Choi MY, Soen CK, Oh HK. Survey for the Disabled. Seoul. Ministry of Health \& Welfare, Korea Institute for Health and Social Affairs; 2009:118-140 (Korean)

3. Testa MA, Simonson DC. Assessment of quality of life outcomes. $N$ Engl $J$ Med 1996;334(13):835-840

4. Drummond MF, O’Brien B, Stodart G, Torrance G. Methods for the Economic evaluation of health care programs. $3^{\text {rd }}$ ed. New York, Oxford University Press, 2005, pp.124-126

5. EuroQol Group. EuroQol: a new facility for the measurement of health-related quality of life. Health Policy 1990;16:199-208

6. Torrance GW, Boyle MH, Horwood SP. Application of multi-attribute utility theory to measure social preferences for health states. Oper Res 1982;30:1043-1069

7. Patric DL, Bush JW, Chen MM. Methods for measuring levels of well-being for a health status index. Health Serv Res 1973;8:228-245

8. Brazier J, Roberts J, Deverill M. The estimation of a preference-based measure of health from the SF-36. J Health Econ 2002;21(2):271-292

9. Fischer U, Anca D, Arnold M, Nedeltchev 
K, Kappeler L, Ballinari P et al. Quality of life in stroke survivors after local intra-arterial thrombolysis. Cerebrovasc dis 2008;25(5):438-444

10. Solli O, Stavem K, Kristiansen IS. Health-related quality of life in diabetes: The associations of complications with EQ-5D scores. Health Qual Life Outcomes 2010;8:18

11. Dolan P. Modeling valuations for EuroQol health states. Med Care 1997;35(11):1095-1108

12. Shaw JW, Johnson JA, Coons SJ. US valuation of the $\mathrm{EQ}^{-} 5 \mathrm{D}$ health states: Development and testing of the D1 valuation model. Med Care 2005;43(3):203-220

13. Tsuchiya A, Ikeda S, Ikegami N, Nishimura S, Saki I, Fukuda $\mathrm{T}$ et al. Estimating an EQ-5D population value set: the case of Japan. Health Econ 2002;11(4):341-353

14. Lee YK, Nam HS, Chuang LH, Kim KY, Yang HK, Kwon IS et al. South Korean time trade-off values for $\mathrm{EQ}^{-5 \mathrm{D}}$ health states: modeling with observed values for 101 health states. Value Health 2009;12(8): 1187-1193

15. Jo MW, Yun SC, Lee SI. Estimating quality weights for $\mathrm{EQ}^{-5 \mathrm{D}}$ health states with the time trade-off method in South Korea. Value Health 2008;11(7):1186-1189

16. Kang EJ, Shin HS, Park HJ, Jo MW, Kim NY. A valuation of health state using EQ-5D. The Korean Journal of Health
Economics and Policy 2006;12(2):19-43 (Korean)

17. Lee KW, Ha MK, Ha KS, Kim RB, Park KS. The association of social support and quality of life of stroke patients in a city. J Agri Med \& Community Health 2010;35(1):46-55 (Korean)

18. Jo MW, Bae HJ. One-year health related quality of life and its comparison with various clinical and functional scale in hospitalized patients with acute ischemic stroke: Seoul National University Bundang Stroke Registry Study. J Korean Neurol Assoc 2009;27(1):28-35 (Korean)

19. Kang EJ, Ko SK. A catalogue of EQ-5D utility weights for chronic disease among noninstitutionalized community residents in Korea. Value Health 2009;12(3):S114-117.

20. Korea Centers for Disease Control and Prevention. The Fourth Korea National Health and Nutrition Examination Survey (KNHANES IV), 2009 (Korean)

21. Ministry of Health and Welfare: The present condition for the registry of persons disabled in 2008; 2009[cited 2011 April 15] Available from: URL: http://stat.mw.go.kr/_common/ board_file_dn.jsp? BOARD_ID=260\&CONT_SEQ= 10955\&FILE_SEQ=1192

22. Brooks R, Rabin R, de Charro F. The measurement and valuation of health status using EQ-5D: A European perspective. Dordrecht, Kluwer Academic Publishers; 2003, pp.103-166 